\title{
Decreased Plasma Clearance and Hepatic Extraction of Aldosterone in Patients with Heart Failure *
}

\author{
C. A. Camargo, A. J. Dowdy, E. W. Hancock, and J. A. Luetscher $\dagger$ \\ (From the Department of Medicine, Stanford University School of Medicine, Palo Alto, Calif.)
}

In experimental congestive heart failure in dogs, the secretion rate of aldosterone is markedly elevated (1). Ayers and his colleagues (2) demonstrated a decreased rate of aldosterone removal from plasma, which results in a further increase in circulating aldosterone in dogs with passive congestion of the liver. Yates, Urquhart, and Herbst (3) showed that constriction of the inferior vena cava above the hepatic veins lowers the $\Delta^{4}$-steroid reductase activity of liver homogenates in rats. Increased levels of sodium-retaining steroids can be correlated with reduced renal excretion of sodium and with the collection of ascites in dogs after stenosis of the pulmonic valve or constriction of the inferior vena cava $(4,5)$.

The role of aldosterone in the edema of clinical congestive heart failure is less clearly defined. Measurements of aldosterone secretion rate in hospitalized patients with congestive heart failure are frequently within normal limits, although some cases show increased secretion (6-8). Recently, three groups of investigators (9-11) have reported that aldosterone removal from plasma is decreased in congestive heart failure. Bougas and his associates (10) showed that aldosterone is almost completely removed from plasma passing through the liver of normal man. In congestive heart failure, however, hepatic extraction may fall as low as $50 \%(9,10)$. The present study was designed to correlate changes in aldosterone secre-

\footnotetext{
* Submitted for publication July 22, 1964; accepted November 5, 1964.

This work was supported by research grant Am-03062 from the National Institutes of Health, which also awarded traineeship T1 AM-5021 and career research support K6-AM-14, 176.

A partial report of this work was read at a sectional meeting of the American Society for Clinical Investigation, May 3, 1964.

$\dagger$ Address requests for reprints to: Dr. J. A. Luetscher, Stanford University School of Medicine, 300 Pasteur Drive, Palo Alto, Calif.
}

tion rate, plasma clearance rate, and splanchnic extraction ratio with measurements of circulatory function obtained at cardiac catheterization.

\section{Methods}

Seventeen patients were studied during cardiac catheterization (Table I). Three were asymptomatic young men with uncomplicated intracardiac left-to-right shunts. The remaining 14 patients had aortic or mitral valve disease of varying type and severity. Six were cardiac invalids with advanced congestive failure, and eight were ambulatory patients with varying disability at the time of study. Cases 4 and 5 had intractable congestive failure with gross edema at the time of study. All others were studied after congestive failure had been controlled by rest and medical therapy. Edema had been evident in all cases with moderate to advanced congestive failure at some previous time, but was present in only three cases at the time of study. The patients were classified into three groups on the basis of clinical assessment of the degree of disability due to heart disease and the circulatory impairment as revealed by cardiac catheterization data. These groups corresponded well with classification according to criteria of the New York Heart Association based on functional capacity (12), i.e., Class IV, advanced congestive failure; Classes III and II, moderate to minimal functional impairment; and Class I, asymptomatic. Within groups the patients are listed in order of ascending cardiac output, although the systemic arteriovenous oxygen difference corresponded better to the clinical impression of severity of cardiac failure and eliminated the overlap between groups that was present in the cardiac output or cardiac index (Table II).

The previous sodium intake was noted and continued. All medications except digitalis were discontinued at least 24 hours before study. On the day preceding or following the study, Bromsulphalein concentration in plasma was measured 45 minutes after injection of $5 \mathrm{mg}$ per kg.

The plasma clearance rate (PCR) of labeled aldosterone was measured by a constant infusion method (13) during cardiac catheterization. The 1,2- $\mathrm{H}^{3}-d$-aldosterone 1 (SA $100 \mu \mathrm{c}$ per $\mu \mathrm{g}$ ) was dissolved in ethanol, stored at $-25^{\circ} \mathrm{C}$, and checked for purity at regular intervals. Immediately before use, solutions of $10 \pm 3 \mu \mathrm{c}$ in $50 \mathrm{ml}$ of

\footnotetext{
1 Supplied by the Endocrinology Study Section, National Institutes of Health.
} 
TABLE I

Clinical data*

\begin{tabular}{|c|c|c|c|c|c|c|c|c|c|}
\hline Case & $\begin{array}{l}\text { Age } \\
\text { and } \\
\text { sex }\end{array}$ & SA & Diagnosis & Rhythm & $\begin{array}{c}\text { Hepato- } \\
\text { megaly }\end{array}$ & $\begin{array}{c}\text { Total } \\
\text { serum } \\
\text { bilirubin }\end{array}$ & $\begin{array}{l}\text { Brom- } \\
\text { sulphalein } \\
\text { reten- } \\
\text { tion }\end{array}$ & $\underset{\text { crit }}{\text { Hemato- }}$ & $\begin{array}{l}\text { Creatinine } \\
\text { clearance }\end{array}$ \\
\hline & & $m^{2}$ & & & & $m g / 100 m l$ & $\%$ & $\%$ & $m l / m i n$ \\
\hline \multicolumn{10}{|c|}{ Advanced congestive failure } \\
\hline 1 & $39 \mathrm{~F}$ & 1.46 & RHD MI, ti & AF & + & 1.2 & 15 & 48 & 46 \\
\hline 2 & $42 \mathrm{~F}$ & 1.42 & RHD MI, AI & $\mathbf{A F}$ & + & 0.6 & 12 & 43 & 89 \\
\hline 3 & $47 \mathrm{~F}$ & 1.77 & RHD MS, mi & AF & - & 0.8 & 6 & 46 & \\
\hline 4 & $48 M$ & 2.1 & RHD AI, ms & NS & + & 2.3 & 27 & 44 & 80 \\
\hline 5 & $56 \mathrm{M}$ & 1.86 & Calcific AS & NS & + & 1.8 & 20 & 40 & 46 \\
\hline 6 & $29 \mathrm{~F}$ & 1.32 & RHD MI, ms & NS & + & 0.7 & & 41 & 57 \\
\hline \multicolumn{10}{|c|}{ Moderate to minimal functional impairment } \\
\hline 7 & $43 \mathrm{~F}$ & 1.37 & RHD MS, mi & AF & + & 1.0 & 3 & 39 & 67 \\
\hline 8 & $49 \mathrm{~F}$ & 1.73 & RHD MS & AF & + & 0.4 & 10 & 46 & 110 \\
\hline 9 & $46 \mathrm{~F}$ & 1.67 & RHD MS & NS & - & 0.5 & 2 & 38 & 85 \\
\hline 10 & $38 \mathrm{M}$ & 1.75 & RHD AI, AS, mi & NS & - & 0.8 & 4 & 39 & 74 \\
\hline 17 & $42 \mathrm{~F}$ & 1.54 & RHD MS & NS & - & & 1 & 37 & 102 \\
\hline 11 & $66 \mathrm{M}$ & 1.63 & Calcific AS & NS & - & & & 40 & 99 \\
\hline 12 & $32 \mathrm{~F}$ & 1.57 & RHD MS & NS & - & 0.5 & 5 & 40 & 95 \\
\hline 13 & $49 \mathrm{M}$ & 1.88 & RHD AS, ai & NS & - & 0.6 & 10 & 42 & 114 \\
\hline \multicolumn{10}{|c|}{ Asymptomatic } \\
\hline 14 & $31 \mathrm{M}$ & 1.82 & Congenital IASD & NS & - & & 3 & 48 & 119 \\
\hline 15 & $18 M$ & 1.84 & Congenital IVSD & NS & - & & & 44 & 151 \\
\hline 16 & $23 \mathrm{M}$ & 1.90 & Congenital IASD & NS & - & & 2 & 47 & 200 \\
\hline
\end{tabular}

* Principal valve lesions capitalized; minor lesions in lower case. $\mathrm{RHD}=$ rheumatic heart disease; $\mathrm{M}=$ mitral; $\mathrm{A}=$ aortic; $\mathrm{T}=$ tricuspid $\mathrm{S}=$ stenosis; I $=$ insufficiency; IA(V)SD $=$ interauricular (ventricular) septal defect. AF $\Rightarrow$ auricular fibrillation; NS $=$ normal sinus rhythm. $+=$ present; $-=$ absent.

isotonic saline were prepared for injection, and samples of this were later counted in a liquid scintillation spectrometer.

All studies were performed between 9 a.m. and noon.
Patients were kept in the recumbent position before, during, and for 24 hours following the study. While the patient was being prepared for catheterization, a priming injection of tritium-labeled aldosterone was given intra-

TABLE II

Cardiac output, oxygen content, and pressures measured during cardiac catheterization

\begin{tabular}{|c|c|c|c|c|c|c|c|c|}
\hline Case & $\begin{array}{c}\text { Cardiac } \\
\text { index }\end{array}$ & $\begin{array}{c}\text { Arterial } \\
\text { oxygen } \\
\text { saturation }\end{array}$ & $\begin{array}{c}\text { Systemic } \\
\text { a-v } \mathrm{O}_{2} \\
\text { difference }\end{array}$ & $\begin{array}{c}\text { Hepatic } \\
\text { a-v } \mathrm{O}_{2} \\
\text { difference }\end{array}$ & $\begin{array}{c}\text { Right } \\
\text { atrial } \\
\text { pressure }\end{array}$ & $\begin{array}{c}\text { Right } \\
\text { ventricular } \\
\text { pressure }\end{array}$ & $\begin{array}{c}\text { Left } \\
\text { ventricular } \\
\text { pressure }\end{array}$ & $\begin{array}{c}\text { Brachial } \\
\text { arterial } \\
\text { pressure }\end{array}$ \\
\hline \multicolumn{9}{|c|}{$\begin{array}{c}m / / 100 \mathrm{ml} m \mathrm{~m} / 100 \mathrm{ml} \quad \mathrm{mm} \mathrm{Hg} \\
\text { Advanced congestive failure }\end{array}$} \\
\hline $\begin{array}{l}1 \\
2 \\
3 \\
4 \\
5 \\
6\end{array}$ & $\begin{array}{l}1.7 \\
1.8 \\
1.9 \\
2.0 \\
2.2 \\
2.2\end{array}$ & $\begin{array}{l}93 \\
94 \\
97 \\
92 \\
92 \\
97\end{array}$ & $\begin{array}{l}8.3 \\
8.5 \\
7.0 \\
9.9 \\
8.4 \\
7.6\end{array}$ & $\begin{array}{r}6.9 \\
\\
9.8 \\
11.6 \\
10.1\end{array}$ & $\begin{array}{r}6 \\
4 \\
3 \\
19 \\
7 \\
6\end{array}$ & $\begin{array}{l}52 / 6 \\
37 / 2 \\
28 / 3 \\
93 / 23 \\
63 / 5\end{array}$ & $132 / 24$ & $\begin{array}{r}100 / 60 \\
148 / 66 \\
109 / 61 \\
167 / 58 \\
95 / 70 \\
104 / 66\end{array}$ \\
\hline \multicolumn{9}{|c|}{ Moderate to minimal failure } \\
\hline $\begin{array}{r}7 \\
8 \\
9 \\
10 \\
17 \\
11 \\
12 \\
13\end{array}$ & $\begin{array}{l}2.0 \\
2.2 \\
2.2 \\
2.5 \\
2.6 \\
2.9 \\
3.4 \\
3.8\end{array}$ & $\begin{array}{l}96 \\
94 \\
96 \\
94 \\
89 \\
94 \\
98 \\
97\end{array}$ & $\begin{array}{l}6.7 \\
6.3 \\
4.9 \\
5.4 \\
4.2 \\
5.1 \\
4.6 \\
5.3\end{array}$ & $\begin{array}{l}5.5 \\
5.6 \\
3.5\end{array}$ & $\begin{array}{l}2 \\
5 \\
4 \\
2 \\
5 \\
3 \\
2 \\
2\end{array}$ & $\begin{array}{l}27 / 0.5 \\
47 / 4 \\
28 / 5 \\
51 / 2 \\
38 / 6 \\
\\
25.4 \\
64 / 3\end{array}$ & $\begin{array}{l}217 / 60 \\
130 / 6 \\
202 / 22\end{array}$ & $\begin{array}{l}134 / 75 \\
102 / 68 \\
115 / 60 \\
107 / 43 \\
110 / 60 \\
139 / 66 \\
127 / 58 \\
136 / 58\end{array}$ \\
\hline \multicolumn{9}{|c|}{ Asymptomatic } \\
\hline $\begin{array}{l}14 \\
15 \\
16\end{array}$ & $\begin{array}{l}2.1^{*} \\
2.9^{*} \\
2.2^{*}\end{array}$ & $\begin{array}{l}97 \\
98 \\
97\end{array}$ & $\begin{array}{l}6.5^{*} \\
4.8^{*} \\
6.7^{*}\end{array}$ & 3.9 & $\begin{array}{l}1 \\
4 \\
3\end{array}$ & $\begin{array}{l}24 / 1 \\
28 / 4 \\
37 / 6\end{array}$ & & $\begin{array}{l}120 / 70 \\
115 / 70 \\
137 / 74\end{array}$ \\
\hline
\end{tabular}

* Based on best estimate of mixed venous blood $\mathrm{O}_{2}$ content. 
venously. After 5 to 20 minutes, an intravenous infusion of tritium-labeled aldosterone was begun at a constant rate of $0.4 \mathrm{ml}$ per minute from a motor-driven syringe. ${ }^{2}$ This infusion was continued for 70 to 120 minutes, during which the right side of the heart was catheterized through a vein of the opposite arm. Pressures were recorded and samples of blood and expired air taken for calculation of resting cardiac output. Expired air was collected for 4 minutes, and $\mathrm{O}_{2}$ and $\mathrm{CO}_{2}$ were measured with a Scholander apparatus (14). Oxygen saturation of blood samples was measured by spectrophotometry (15).

After the infusion of labeled aldosterone had run for 60 to 90 minutes, three samples of arterial blood (or, in a few cases, blood from a peripheral vein) were drawn at intervals of 3 to 10 minutes into heparinized syringes. In nine patients, simultaneous samples were drawn slowly from a catheter placed deep, but not wedged, into a right hepatic vein. The position of the catheter was documented with an X-ray film. To correct for losses of labeled aldosterone during subsequent purification, $20 \mu \mathrm{g}$ of nonradioactive aldosterone was added to each plasma

2 Harvard Apparatus Co., Dover, Mass. sample before extraction. Recovery was determined by fluorimetric measurement of aldosterone diacetate after addition of $\mathrm{K}$-tert-butoxide as described by Abelson and Bondy (16). In a majority of cases, recovery was also estimated by adding $125 \mathrm{dpm}$ of $\mathrm{C}^{14}$-labeled aldosterone to each plasma sample. The plasma was extracted 4 times with 1 vol of methylene dichloride. The extracts of each sample were pooled, dried, and chromatographed on paper in Bush B4 system (17). The fraction containing aldosterone was eluted, dried, acetylated, and purified as previously described (18). Tritium and carbon ${ }^{14}$ in the purified aldosterone diacetate were counted in a liquid scintillation spectrometer until random variation was less than $3 \%$ of corrected counts per minute.

Concentration of $\mathrm{H}^{3}$-aldosterone in plasma is shown in Table III. Of the 14 cases in which three or more samples of peripheral plasma were obtained, ten cases showed no discernible trend in radioactivity with time after 60 minutes of infusion. In these ten cases, the mean coefficient of variation was $3.8 \%$, with a range of 1.5 to $6.3 \%$. The plasma clearance rate (PCR) of aldosterone has been calculated from the formula: PCR (liters per minute) =

TABLE III

$H^{3}$-aldosterone in plasma during infusion, rate of clearance from plasma, and hepatic extraction

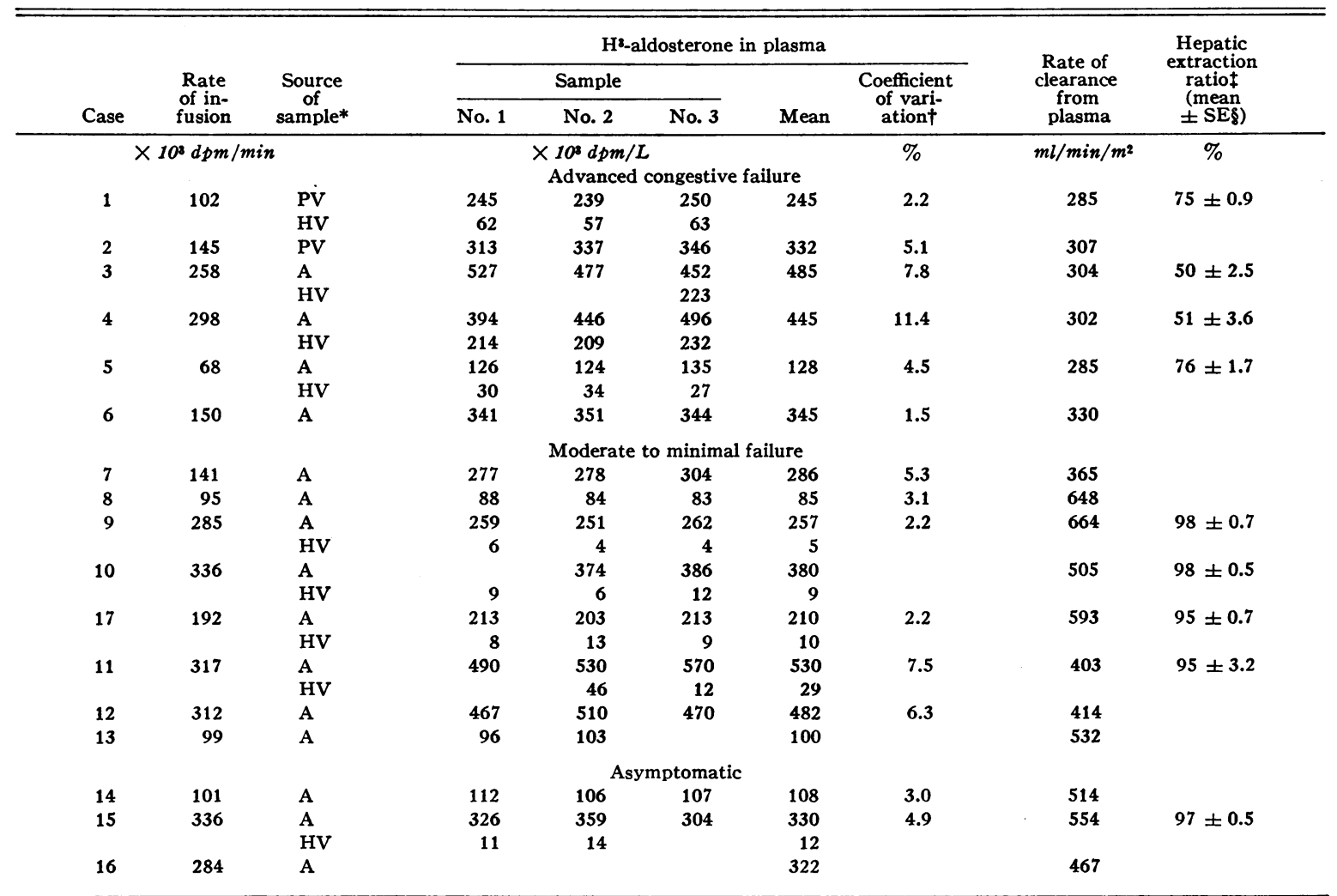

$* \mathrm{PV}=$ peripheral vein $\mathrm{HV}=$ hepatic vein $; \mathrm{A}=$ artery

+ Coefficient of variation $=100 \times \mathrm{SD} / \mathrm{mean}$. level.

The hypothesis that the hepatic extraction ratio is the same in advanced congestive failure as in the other cases can be rejected at the 0.016 
TABLE IV

Aldosterone secretion rate, plasma clearance, and estimated plasma concentration

\begin{tabular}{|c|c|c|c|c|c|c|}
\hline Case & $\begin{array}{l}\text { Secretion } \\
\text { rate }\end{array}$ & $\begin{array}{l}\text { Plasma } \\
\text { clearance } \\
\text { rate }\end{array}$ & 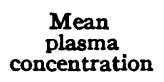 & $\begin{array}{l}\text { Sodium } \\
\text { intakef }\end{array}$ & $\begin{array}{l}\text { Urine } \\
\text { sodium }\end{array}$ & $\begin{array}{c}\text { Urine } \\
\text { potassium }\end{array}$ \\
\hline & $\mu g / d a y$ & $L / d a y$ & $m \mu g / 100 \mathrm{ml}$ & $m E q / d a y$ & $m E q / d a y$ & $m E q / d a y$ \\
\hline $\begin{array}{l}1 \\
2 \\
3 \\
4 \\
5 \\
6\end{array}$ & $\begin{array}{l}110 \\
270 \\
190 \\
110 \\
400 \\
50\end{array}$ & $\begin{array}{l}600 \\
630 \\
775 \\
910 \\
765 \\
630\end{array}$ & $\begin{array}{r}18 \\
43 \\
24 \\
12 \\
52 \\
8\end{array}$ & $\begin{array}{l}65 \\
87 \\
40 \\
87 \\
22 \\
40\end{array}$ & $\begin{array}{r}132 \\
14 \\
18 \\
49 \\
1 \\
13\end{array}$ & $\begin{array}{r}92 \\
45 \\
85 \\
112 \\
15 \\
13\end{array}$ \\
\hline $\begin{array}{r}7 \\
8 \\
10 \\
17 \\
11 \\
12 \\
13\end{array}$ & $\begin{array}{r}344 \\
160 \\
288 \\
140 \\
91 \\
160 \\
153\end{array}$ & $\begin{array}{c}\text { Moder } \\
720 \\
1,610 \\
1,270 \\
1,360 \\
850 \\
940 \\
1,440\end{array}$ & $\begin{array}{c}\text { to minimal fa } \\
48 \\
10 \\
23 \\
10 \\
11 \\
17 \\
11\end{array}$ & $\begin{array}{r} \\
40 \\
87 \\
40 \\
87 \\
87 \\
110 \\
\text { NR }\end{array}$ & $\begin{array}{r}2 \\
55 \\
28 \\
80 \\
88 \\
26 \\
223\end{array}$ & $\begin{array}{l}47 \\
51 \\
49 \\
44 \\
52 \\
57 \\
92\end{array}$ \\
\hline $\begin{array}{l}14 \\
15 \\
16\end{array}$ & $\begin{array}{r}50 \\
103 \\
130\end{array}$ & $\begin{array}{l}1,350 \\
1,470 \\
1,270\end{array}$ & $\begin{array}{c}\text { mptomatic } \\
4 \\
7 \\
10\end{array}$ & $\begin{array}{l}\text { NR } \\
\text { NR } \\
\text { NR }\end{array}$ & $\begin{array}{l}146 \\
250 \\
109\end{array}$ & $\begin{array}{r}69 \\
121 \\
79\end{array}$ \\
\hline $\begin{array}{c}\text { C1* } \\
\text { Mean } \\
\text { C2* } \\
\text { Mean } \\
\text { C3* } \\
\text { Mean }\end{array}$ & $\begin{array}{c}40-180 \\
108 \\
45-255 \\
128 \\
60-210 \\
111\end{array}$ & $\begin{array}{c}1,020-2,125 \\
1,630 \\
970-1,814 \\
1,340\end{array}$ & $\begin{array}{c}3-15 \\
7.7 \\
4-12 \\
7.4\end{array}$ & $\begin{array}{l}\text { NR } \\
\text { NR } \\
\text { NR }\end{array}$ & $\begin{array}{c}83-240 \\
135\end{array}$ & $\begin{array}{c}43-159 \\
71\end{array}$ \\
\hline
\end{tabular}

* C1: normal, $6 \sigma^{\top}, 4$ ㅇ (18); C2 : convalescent, 13 \% $(13,19)$; C3: euthyroid, $4 \sigma^{\top}, 3$ ㅇ (20).

$\dagger \mathrm{NR}=$ unrestricted.

rate of $\mathrm{H}^{3}$-aldosterone infusion (disintegrations per minute per minute)/plasma concentration of $\mathrm{H}^{3}$-aldosterone (disintegrations per minute per liter). The PCR has been expressed in Table III as milliliters of plasma per minute per square meter of body surface area to permit comparison with the cardiac index in Table II.

The calculation of PCR is valid only if a steady state of $\mathrm{H}^{3}$-aldosterone turnover has been reached. Inspection of Table III suggests a rising trend of plasma tritium in three cases and a falling trend in one case. In the other ten cases, no trend is visible; but in four of these, the three plasma samples were drawn within 15 minutes, which diminished the probability of detecting a change of plasma radioactivity with time. To gain further information, plasma samples were drawn from nine of the patients 30 minutes after the start of the infusion and at intervals after discontinuing the infusion. The data were compared with values predicted by Tait and co-workers' two-compartment model (13). With the aid of an electrical analog computer, the volumes of distribution and clearance rates were adjusted for best fit to the experimental data. In Case 4 , who was a large man with a low PCR of aldosterone, the required increase in the priming dose relative to the rate of infusion was not anticipated; consequently, the plasma level approached equilibrium unusually slowly. The computed PCR was at least $15 \%$ lower than the calculated value given in Table III, which is probably higher than the true PCR of aldosterone in this patient with intractable congestive failure. In the other eight cases, computed results agreed well with the data given in Table III: the mean ratio of computed PCR to calculated PCR was 0.98 , with a range of 0.90 to 1.05 . Since the computed PCR is not dependent on the assumption of a steady state, the good correspondence between computed and calculated values suggests that equilibrium was approached in eight of the nine cases tested.

Urine was collected for 24 hours following the injection of labeled hormone. Aldosterone secretion rate was measured by the method of Siegenthaler, Dowdy, and Luetscher (18). Completeness of collection was checked by measurement of urine creatinine and counting of total tritium excreted. A sample of urine was taken for determination of sodium, potassium, and 17-hydroxycorticoids.

Plasma aldosterone concentration was estimated by dividing secretion rate (micrograms per day) by PCR (liters per day). The estimated range of 3 to $15 \mathrm{~m} \mu \mathrm{g}$ per $100 \mathrm{ml}$ plasma previously reported in normal subjects on unrestricted diets $(19,20)$ agrees well with a recent 


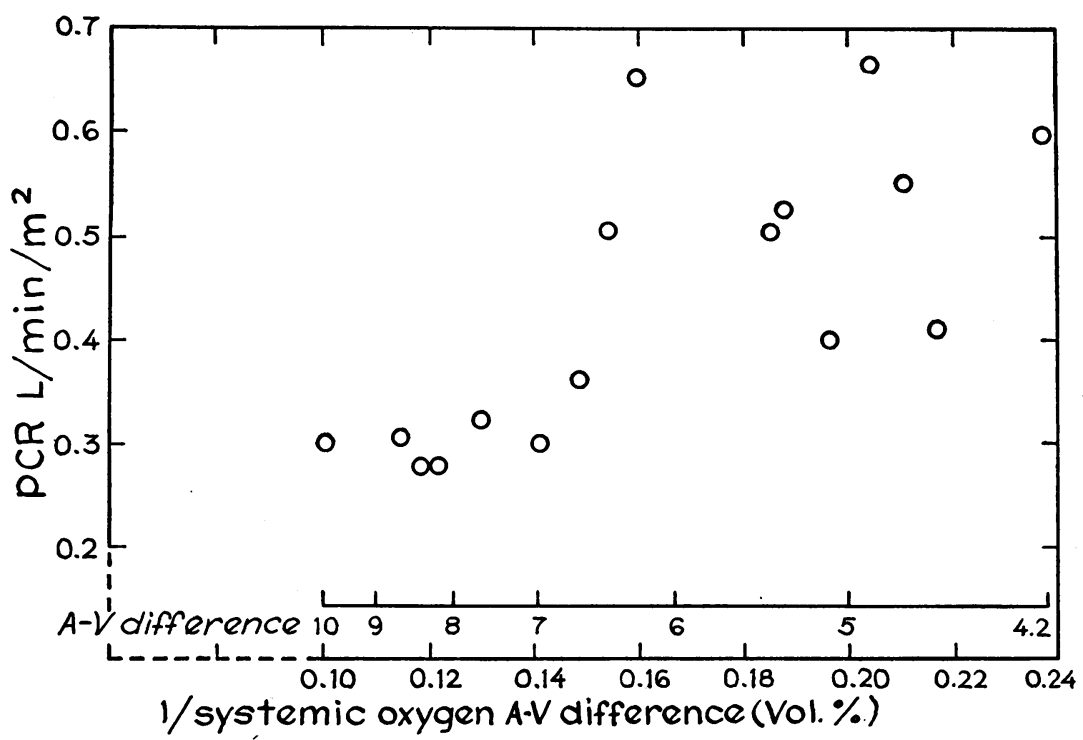

Fig. 1. Correlation of the plasma clearance rate (PCR) of aldosterone WITH THE INVERSE OF SYSTEMIC ARTERIOVENOUS (A-V) OXYGEN DIFFERENCE. The $r$ is 0.72 ; the probability of independence is less than 0.001 .

report of analytical results with an isotopic derivative method (21). It was assumed that postural and diurnal variations in secretion and clearance were minimal in recumbent subjects $(10,22)$. In three instances, urine was collected from 9 a.m. to 3 p.m. on the day of catheterization and from 3 p.m. to the following morning. Ex- cretion of the acid-labile conjugate of endogenous aldosterone, expressed as micrograms per hour, was not significantly different in the day versus the night in any case. The consistently normal excretion of 17-hydroxycorticoids on the day of the test indicated that unusual stimulation of the adrenal cortex by pituitary

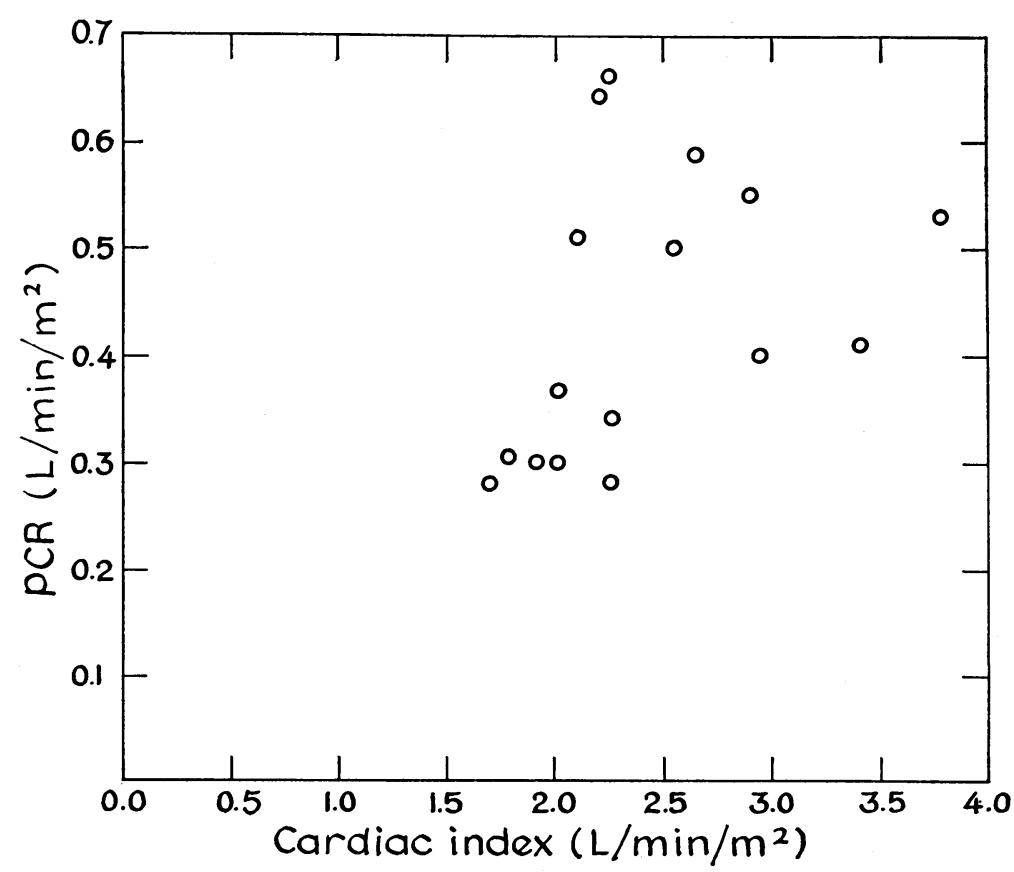

Fig. 2. Correlation of the plasma clearance rate of aldosterone WITH THE CARDIAC INDEX. The $r$ is 0.395 ; the probability of independence is between 0.05 and $\mathbf{0 . 1 0}$. 
ACTH had not been evoked by the procedure. These tests suggest that variations in secretion rate due to stress or diurnal rhythm were not so large as to disturb the steady state appreciably. Plasma clearance rates of aldosterone, measured during cardiac catheterization in the asymptomatic subjects and those with minimal cardiac disability, are within the range previously observed in normal subjects (Table IV). These findings suggest that cardiac catheterization did not disturb the measured functions to such an extent as to invalidate the calculations or the comparison with data previously obtained in other subjects.

To compensate for the smaller quantity of $\mathrm{H}^{3}$-aldosterone in hepatic vein plasma, a larger volume of plasma (25 ml vs. $15 \mathrm{ml}$ of arterial plasma) was extracted, a smaller quantity of $\mathrm{C}^{14}$-aldosterone (60 dpm per sample) was added, and counting time was increased to keep random variation below $3 \%$ of corrected counts. The hepatic extraction ratio, calculated as (artery-hepatic vein)/ artery, is given in Table III, together with an estimate of the standard error.

\section{Results}

The PCR of aldosterone was below normal in all six of the patients considered to have severe disa- bility and was reduced in three of the eight patients with slight or moderate disability (Table III). A significant inverse correlation between PCR and systemic arteriovenous oxygen difference was demonstrated (Figure 1). There was a less definite indication of a relationship between PCR and cardiac output (Figure 2). Patients with reduced PCR also showed a greater incidence of hepatomegaly, Bromsulphalein retention, reduced creatinine clearance, arterial oxygen unsaturation, and raised right atrial pressure than those with normal PCR (Tables I and II).

The splanchnic extraction ratio of aldosterone was normal (95 to $98 \%$ ) in five patients with minimal circulatory impairment and substantially reduced (50 to $76 \%$ ) in all four patients with advanced congestive failure from whom hepatic venous samples were obtained. Reduced splanchnic aldosterone extraction was associated with reduced hepatic venous oxygen saturation and wide hepatic arteriovenous oxygen difference in all four instances; three of these cases also showed

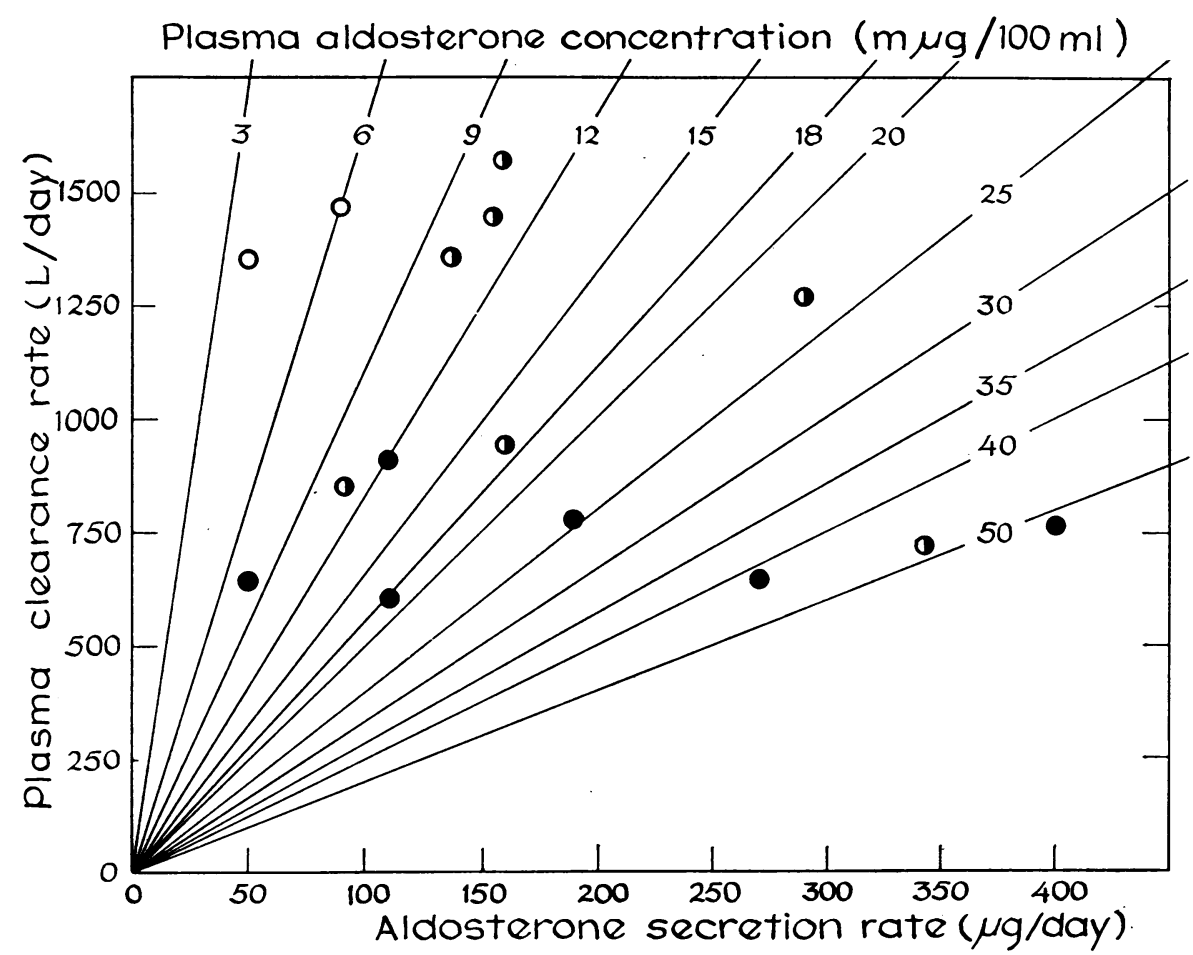

Fig. 3. Plasma clearance and secretion rate of aldosterone. Diagonal lines indicate ratios between secretion rate and PCR, corresponding to given mean estimated concentrations of aldosterone in plasma. Cases with advanced heart failure are shown as solid dots. Those with moderate circulatory impairment are shown as half-closed circles. Asymptomatic subjects are indicated by open circles. 
elevated right atrial pressure and evidence of reduced plasma clearance of bilirubin and Bromsulphalein.

The secretion rate of aldosterone was within normal limits ( 40 to $180 \mu \mathrm{g}$ per day) in 11 of 16 patients, including all of the asymptomatic patients and those with minimal congestive failure, who were ingesting $87 \mathrm{mEq}$ of sodium or more per day (Table IV). The five patients with increased secretion rate included three with advanced disability and two with moderate disability; four of these five patients with increased secretion rates were ingesting less than $87 \mathrm{mEq}$ of sodium per day.

The plasma aldosterone concentration was calculated to be substantially elevated in the five patients with increased secretion rate; plasma clearance was decreased in four of the five patients (Figure 3 ). Two additional cases were considered to have borderline high plasma aldosterone levels on the basis of normal secretion rates associated with reduced plasma clearance rates.

Increased plasma aldosterone concentration was associated with low urinary sodium excretion. The rank $\mathrm{r}$ was 0.67 , indicating an association significant at the $1 \%$ level. Estimated plasma aldosterone concentration also showed a highly significant correlation with the inverse of urine sodium and with potassium-to-sodium ratio in urine. When the latter two quantities were expressed as functions used by Johnson (23) to minimize variability arising from very high or low electrolyte excretion in bioassay of sodium-retaining steroids, the $r$ with plasma aldosterone concentration were 0.87 and 0.89 .

\section{Discussion}

Increased plasma concentration of aldosterone might occur with either increased secretion rate or with decreased removal rate of the hormone. Abnormalities in both secretion and removal are present in patients with congestive heart failure, and multiple factors need to be considered in the mechanism of these abnormalities.

In this study, it was not possible to control certain factors known to affect aldosterone secretion. The relation of a low sodium intake to increased aldosterone secretion in normal men is recognized (7). In the present series, the association of dietary sodium and aldosterone secretion is of borderline significance at the 0.05 level. Previous diuretic therapy may also have contributed to increased secretion rate. Changes in sodium intake in patients with heart failure do not consistently evoke a normal response (8) and may cause "paradoxical" changes in aldosterone secretion (7). No conclusions concerning the cause of increased secretion rate are possible in the five cases with congestive failure and low sodium diets. Secretion rate was normal in some patients on low sodium diets, however, and plasma aldosterone concentration could be elevated in such patients when the rate of removal from plasma was low.

The principal site of removal of aldosterone from plasma is thought to be in the liver. A decrease in hepatic removal rate could result from reduced hepatic blood flow or from reduced hepatic extraction ratio owing to liver cell dysfunction. In the patients with moderate cardiac disability, hepatic extraction of aldosterone was nearly complete (95 to $98 \%$ ), and there was no evidence of liver cell dysfunction. The reduced plasma clearance rate in three patients of this group probably resulted from reduced hepatic blood flow in association with reduced or low normal cardiac output. Myers and Hickam (24) showed that there is a regression of hepatic blood flow with falling cardiac output in congestive heart failure.

In patients with advanced congestive heart failure, the reduction in plasma clearance rate of aldosterone was greater and was accompanied by a fall in the splanchnic extraction ratio to between 50 and $75 \%$ in all cases in which hepatic vein blood was obtained. It is not necessary to assume a further decrease in hepatic blood flow in this group, since the reduced hepatic extraction ratio could account for reduced hepatic removal without further reduction in blood flow.

If the plasma clearance rate of aldosterone is compared with the cardiac output, and if it is assumed that aldosterone is removed only by the liver, it would appear that more than half of the cardiac output was passing through the liver in Cases 3 and 4. We have already pointed out that PCR may have been overestimated in Case 4 due to failure to reach equilibrium. Rapaport, Weisbart, and Levine (25) and Tait and associates (26) have reported that hepatic blood flow may represent a large fraction of cardiac output in cer- 
tain cases with severe congestive failure. An alternative explanation would be that a significant fraction of aldosterone cleared from plasma is removed in sites outside the liver. There is evidence that extrahepatic metabolism occurs (26, 27 ), but its magnitude is difficult to estimate from data available at present.

Decreased hepatic extraction of aldosterone probably results from reduced oxygen tension, due to continued oxygen consumption with falling hepatic blood flow and increased transit time of blood flowing through the congested liver $(24,25)$. Marked central venous dilation and hemorrhagic hepatic cellular necrosis were found at autopsy in Cases 4 and 5, who expired within 2 weeks after the study. Sherlock (28) has noted such changes in liver biopsies from patients with progressive congestive heart failure and demonstrated a correlation of liver cell necrosis with diminished clearance of bilirubin and Bromsulphalein. The observations of Yates and co-workers (3) suggest that an enzymatic defect may accompany these visible evidences of hepatic congestion and hypoxia.

Clinical and experimental heart failure is usually associated with increased pressure in the right atrium. The resulting passive congestion of the liver is a possible cause of hepatic dysfunction. In the four patients with impaired hepatic extraction of aldosterone, the right atrial pressure was markedly raised in one and slightly raised in two. The fourth patient (Case 3) had a normal right atrial pressure, and the liver was not palpably enlarged. In all five patients with normal hepatic extraction, the right atrial pressure was normal. Thus, while passive congestion of the liver may be a contributory factor in some cases, aldosterone extraction may be reduced at a time when right atrial pressure is normal.

Plasma aldosterone concentration was clearly increased in five of 13 patients with congestive failure and was slightly above the normal range in two other cases. If aldosterone is playing an appreciable role in the control of electrolyte excretion in these patients, plasma aldosterone concentration would be expected to show an inverse correlation with urinary sodium excretion or with the sodium to potassium ratio in urine, as noted in earlier work (29). The rank correlation test was used, since it does not involve assumptions concerning the distribution of the two variables. The results indicate a probable association of high plasma aldosterone with low urinary sodium and with low urinary sodium to potassium ratio. This interdependence does not necessarily indicate a cause and effect relationship. Sanders and Melby (30) have provided additional evidence, showing that increased sodium excretion followed the administration of spironolactone in $40 \%$ of their patients with congestive failure. Since all of the cases who responded to the aldosterone antagonist did not excrete increased amounts of aldosterone metabolites in urine, the authors suggested that a reduced rate of removal from plasma may have increased the circulating level of hormone. Further work will be necessary to evaluate other factors that sensitize the animal with congestive failure to the sodium-retaining effect of adrenal steroids $(31,32)$.

The patients in this study are a representative group of cases undergoing cardiac catheterization, but they do not include all types of heart disease. Furthermore, the patients were studied during hospitalization, in the recumbent position, and at a time when overt symptoms of congestive failure had been controlled as far as feasible by rest and medical therapy. It is possible that abnormalities of aldosterone metabolism would be more obvious in patients studied under different conditions.

\section{Summary}

The secretion rate and clearance of aldosterone from plasma were measured in 17 patients during cardiac catheterization. In nine cases, the hepatic extraction ratio of aldosterone was determined. Three patients had asymptomatic septal defects, and 14 had valvular heart disease with functional impairment varying from minimal to advanced congestive heart failure. All had received prior medical treatment. Studies were made in the recumbent position.

Aldosterone secretion rate was increased in five cases with heart failure, who had received a low sodium intake and previous diuretic therapy.

The clearance of labeled aldosterone from plasma was decreased in patients with moderate or advanced congestive failure. This decrease was better correlated with increased systemic arteriovenous oxygen difference than with reduced 
cardiac output and was attributed at least in part to reduced hepatic blood flow.

The hepatic extraction ratio of aldosterone was below normal in cases with advanced congestive heart failure. Impaired hepatic extraction was attributed to hepatic cellular dysfunction, chiefly due to anoxia as demonstrated by markedly reduced hepatic venous oxygen saturation. Impaired hepatic extraction was also associated with elevated right atrial pressure in three of four instances.

Reduced clearance of aldosterone implies a proportional increase in the estimated plasma aldosterone concentration for any given rate of secretion. The highest estimates of plasma aldosterone concentration were seen in those patients with moderate to severe failure, in whom both increased secretion and reduced clearance occurred. Increased plasma aldosterone was associated with decreased sodium excretion in the urine.

\section{Acknowledgments}

The authors are grateful to Drs. W. Fowkes, H. Hubis, and C. E. Rotem for performing cardiac catheterizations; to Mrs. B. Burckhardt and Mr. G. Nokes for valuable technical assistance; to the Endocrinology Study Section, National Institutes of Health, for generous gifts of labeled aldosterone; to Drs. J. P. Bunker and J. W. Bellville for making the electrical analog computer available; and to Dr. David B. Hill of the Department of Statistics for advice and assistance.

\section{References}

1. Davis, J. O., M. M. Pechet, W. C. Ball, Jr., and M. J. Goodkind. Increased aldosterone secretion in dogs with right-sided congestive heart failure and in dogs with thoracic inferior vena cava constriction. J. clin. Invest. 1957, 36, 689.

2. Ayers, C. R., J. O. Davis, F. Lieberman, C. C. J. Carpenter, and M. Berman. The effects of chronic hepatic venous congestion on the metabolism of $d, l$-aldosterone and $d$-aldosterone. $\mathrm{J}$. clin. Invest. 1962, 41, 884.

3. Yates, F. E., J. Urquhart, and A. L. Herbst. Impairment of the enzymatic inactivation of adrenal cortical hormones following passive venous congestion of the liver. Amer. J. Physiol. 1958, 194, 65.

4. Davis, J. O., D. S. Howell, and R. E. Hyatt. Sodium excretion in adrenalectomized dogs with chronic cardiac failure produced by pulmonary artery constriction. Amer. J. Physiol. 1955, 183, 263.
5. Davis, J. O. Mechanisms of salt and water retention in congestive heart failure. The importance of aldosterone. Amer. J. Med. 1960, 29, 486.

6. Muller, A. F., R. Veyrat, and E. L. Manning. Etude de la sécrétion de l'aldostérone par l'aldostérone marquée au tritium. Helv. med. Acta 1959, 26, 714.

7. Laragh, J. H. Hormones and the pathogenesis of congestive heart failure: vasopressin, aldosterone, and angiotensin. II. Further evidence for renaladrenal interaction from studies in hypertension and in cirrhosis. Circulation 1962, 25, 1015.

8. Cox, J. R., B. Singer, and D. Verel. The relationship between urinary aldosterone, plasma volume, extracellular fluid volume and total body water. Clin. Sci. 1959, 18, 569.

9. Luetscher, J. A., C. A. Camargo, A. P. Cohn, A. J. Dowdy, and A. M. Callaghan. Observations on metabolism of aldosterone in man. Ann. intern. Med. 1963, 59, 1.

10. Bougas, J., C. Flood, B. Little, J. F. Tait, S. A. S. Tait, and R. Underwood. Dynamic Aspects of the Metabolism of Aldosterone. Council for International Organizations of Medical Sciences Symposium on Aldosterone. Oxford, Blackwell, 1964.

11. Wolff, H. P. Hyperaldosteronism in Edema. Council for International Organizations of Medical Sciences Symposium on Aldosterone. Oxford, Blackwell, 1964.

12. New York Heart Association. Diseases of the Heart and Blood Vessels: Nomenclature and Criteria for Diagnosis, 6th ed. Boston, Little, Brown, 1964.

13. Tait, J. F., B. Little, S. A. S. Tait, and C. Flood. The metabolic clearance rate of aldosterone in pregnant and nonpregnant subjects estimated by both single-injection and constant-infusion methods. J. clin. Invest. 1962, 41, 2093.

14. Scholander, P. F. Analyzer for accurate estimation of respiratory gases in one-half cubic centimeter samples. J. biol. Chem. 1947, 167, 235.

15. Nahas, G. G. Spectrophotometric determination of hemoglobin and oxyhemoglobin in whole hemolyzed blood. Science 1951, 113, 723.

16. Abelson, D., and P. K. Bondy. Fluorometric determination of $\Delta^{4}$-3-ketosteroids. Arch. Biochem. 1955, 57, 208.

17. Bush, I. E. Methods of paper chromatography of steroids applicable to the study of steroids in mammalian blood and tissues. Biochem. J. 1952, 50, 370.

18. Siegenthaler, W. E., A. Dowdy, and J. A. Luetscher. Determination of the secretion rate of aldosterone in normal man by use of $7-\mathrm{H}^{3}-d$-aldosterone and acid hydrolysis of urine. J. clin. Endocr. 1962, 22, 172.

19. Tait, J. F., S. A. S. Tait, B. Little, and K. R. Laumas. The disappearance of $7-\mathrm{H}^{3}-d$-aldosterone in the plasma of normal subjects. J. clin. Invest. 1961, 40, 72. 
20. Luetscher, J. A., A. P. Cohn, C. A. Camargo, A. J. Dowdy, and A. M. Callaghan. Aldosterone secretion and metabolism in hyperthyroidism and myxedema. J. clin. Endocr. 1963, 23, 873.

21. Peterson, R. E., and B. Miller. Determination of peripheral plasma aldosterone. The Endocrine Society, Program of the 46th Meeting, June 1964.

22. Luetscher, J. A., A. J. Dowdy, A. R. Arnstein, C. P. Lucas, and C. L. Murray. Idiopathic Oedema and Increased Aldosterone Excretion. Council for International Organizations of Medical Sciences. Symposium on Aldosterone. Oxford, Blackwell, 1964.

23. Johnson, B. B. Bioassay of adrenal cortical steroids on the basis of electrolyte excretion by rats. Effects of 11-desoxy and 11-oxy-steroids. Endocrinology 1954, 54, 196.

24. Myers, J. D., and J. B. Hickam. An estimation of the hepatic blood flow and splanchnic oxygen consumption in heart failure. J. clin. Invest. 1948, 27, 620.

25. Rapaport, E., M. H. Weisbart, and M. Levine. The splanchnic blood volume in congestive heart failure. Circulation 1958, 18, 581.

26. Tait, J. F., J. Bougas, B. Little, S. A. S. Tait, and C. Flood. The splanchnic extraction and clear- ance of aldosterone in subjects with minimal and marked cardiac dysfunction. J. clin. Endocr. 1965, in press.

27. Luetscher, J. A., C. A. Camargo, E. W. Hancock, A. J. Dowdy, and G. W. Nokes. Observations of aldosterone metabolism in congestive heart failure. Trans. Ass. Amer. Phycns 1964, 77, 224.

28. Sherlock, S. The liver in heart failure. Relation of anatomical, functional, and circulatory changes. Brit. Heart J. 1951, 13, 273.

29. Wolff, H. P., K. R. Koczorek, E. Buchborn, and G. Rieker. Endocrine factors. J. chron. Dis. 1959, 9, 554.

30. Sanders, L. L., and J. C. Melby. Aldosterone and the edema of congestive heart failure. Arch. intern. Med. 1964, 113, 331.

31. Barger, A. C., F. P. Muldowney, and M. R. Liebowitz. Role of the kidney in the pathogenesis of congestive heart failure. Circulation 1959, 20, 273.

32. Davis, J. O., J. E. Holman, C. C. J. Carpenter, J. Urquhart, and J. T. Higgins, Jr. An extra-adrenal factor essential for chronic renal sodium retention in presence of increased sodium-retaining hormone. Circulat. Res. 1964, 14, 17.

\section{ANNOUNCEMENT OF MEETINGS}

The American Federation for Clinical Research will hold its Twentysecond Annual Meeting in Atlantic City, N. J., at the Casino Theater on the Steel Pier on Sunday, May 2, 1965, at 9:00 a.m. Joint sectional meetings with The American Society for Clinical Investigation will be held on Sunday afternoon at Chalfonte-Haddon Hall, and additional meetings sponsored by The American Federation for Clinical Research will be held on Sunday evening.

The American Society for Clinical Investigation, Inc., will hold its Fifty-seventh Annual Meeting in Atlantic City, N. J., on Monday, May 3, at 9:00 a.m., at the Casino Theater on the Steel Pier, and will join The American Federation for Clinical Research in simultaneous sectional meetings on Sunday afternoon, May 2, in Chalfonte-Haddon Hall.

The Association of American Physicians will hold its Seventy-eighth Annual Meeting in Atlantic City, N. J., at the Casino Theater on the Steel Pier on Tuesday, May 4, at 9:30 a.m., and in the Carolina Room, Chalfonte-Haddon Hall, on Wednesday, May 5, at 9:30 a.m. 